\title{
有節ラミ十の縦引張強度に関する統計論的研究 \\ A STATISTICAL STUDY ON TENSILE STRENGTHS \\ OF LAMINAE WITH KNOTS
}

\author{
井戸田 秀樹*
}

Hideki IDOTA

\begin{abstract}
The purpose of this study is to discuss the statistical properties of the tensile strength of laminae with knots for glue laminated wood beams. In this paper, the diameter of knots, the longitudinal distance between two knots, and the tensile strength of knotted laminae are treated as random properties of knots. These properties are modeled stochastically based on the measured and experimental data. The stochastic model for knot randomness are employed to evaluate the percentile strength of knotted laminae by the Monte Carlo simulation and numerical calculations using probability distribution functions. According to the numerical results, the relationships between the basic knot diameter - lamina width ratio for the grading and the percentile value of tensile strengths are examined.
\end{abstract}

\section{1. 序}

集成材の耐力は節や目切れ等の材料的な不連続点に起因する破 壊によって決定される場合が多い。欠点の中でも特に節部分の破 壊は, 節穴の断面欠損だけでなく, 節近傍の繊維の乱れによる応 力集中からも引き起こされる4。したがって, 節径比と強度の関係 にはかなりのばらつきが存在するため，このランダム性を統計的 に扱った強度評価が不可欠である。節の強度やその存在位置, あ るいは出現頻度のランダム性を考愿した木㥸構造材の耐力評価に 関しては，その確率論的評価方法を中心にいくつかの報告がなさ れている5)ー7〕。かし，集成材の欠点自体の強度特性に関しては， 実験や解析に基づく幾つかの成果が報告されているものの番 ${ }^{811, ~}$ 集成材としての酎力のランダム性の統計的な評価に応用可能な確 率モデルを構築するに十分な量のデータが整理されているとは言 い難い。また, 集成材の耐力を統計的に評価するには, 節の強度 だけでなく, 節サイズのランダム性, 節の出現頻度のランダム性 など, 従来ほとんど取り扱われていないような不確定要因も総合 的に評価する必要がある。

そこで本研究では，欠点のランダム性を考慮した集成材の統計 諭的耐力評価の基礎段階として，木質集成材の耐力評価に必要な 有節ラミナの縦引張強度に関して統計論的な考察を行うことを目 的とする。一般的にはラミナの引張強度は材の曲げヤング係数と 相関があると言われているが, 節の位置や出現頻度のランダム性 を考慮した確率論的な強度のモデル化を行うには, 目視などで得
られる節の大きさと強度の関係を統計的に明らかにする必要があ る。そのため，本論文ではまず，節の大きさや出現頻度に関わる 基本統計量として，節の大きさおよび繊維方向に対する節の出現 頻度を実測調査する。また, 節部分の強度に関しては有節ラミナ の縦引張強度実験を行い, 節径比からみた強度の統計的な整理を 行う。次にこうして得られた節のランダム性に関する統計デー 夕に基づき，節径比のランダム性を考慮した縦引張強度のモンテ カルロシミュレーションを行い, 節径比からみた縦引張強度に関 する統計量を提示するとともに，ラミナの等級区分に用いる節径 比の基準值と引張強度分布の関係についての検討も行う。

なお，節の存在を考慮した木質構造材の曲げ耐力評価にあたっ ては，節部分のランダム性だけでなく，部材内における節の存在 位置や曲げ強度の確率論的モデルを構築する必要があるが，これ らに関しては稿を改めて述べる。

\section{2. 節のランダム性に関わる基本統計量}

節のランダム性に関わる基本統計量として, 本論文では節径, 節 間隔および節部分の引張強度の 3 項目を対象とする。

\section{1 節径}

調查対象とした樹種は北米材のベイマツであり，曲げ性能試験 によるヤング率が90〜 150t/ $\mathrm{cm}^{2}$ のものから無作為に抽出した幅が $90 \mathrm{~mm} \sim 236 \mathrm{~mm}$ ，板厚が $35 \mathrm{~mm} \sim 38 \mathrm{~mm}$ の構造用集成材のラミナ である。

節径比算出に用いる節径は，材長と直角方向の径 $d$ に加え，材長 
方向の節径 $d_{C}$, 長径 $d_{L}$, 短径 $d_{s}$ も合わせて測定した (Fig. 1 参照)。 各節径の統計量を Table 1に, dのヒストグラムを Fig. 2に示す。確 率分布形状は右裾の伸びた非対称形で，対数正規分布，ガンマ分 布，極值 I 型分布および指数分布の 4 分布形を対象とした K-S 検 定の結果, 対数正規分布およびガンマ分布が高い適合度を示した。 2.2 節間隔

切り出したラミナにおける節の材長方向への分布を考えると， 節はどの位置でもランダムに存在可能である。また，ある任意の 区間での節の存在は，それと重複しない他の任意の区間に対して 独立と考えられる。このことから，ラミナの材長方向における節 の存在は，ポアソン確率過程に従う事象と仮定できる。すなわち， ラミナの材長方向に沿ったある区間 $a$ における節の存在個数を $K_{i}$ とすると, $K_{i}$ が $x$ 個である確率 $P\left(K_{i}=x\right)$ は

$$
P\left(K_{i}=x\right)=\frac{(v a)^{x}}{x !} e^{v a}
$$

と表わされる。ここに $v$ は単位長さあたりの節の平均発生数であ る。節の存在が(1)式のポアソン確率過程で表されるとき，節と節 の間隔 $\Lambda$ は指数分布に従う確率変数となる。ムはポアソン確率過 程における初期生起間隔であり， $\Lambda$ の確率分布関数 $F_{\Lambda}(d)$ ，および 確率密度関数 $f_{\Lambda}(d)$ は

$$
\begin{aligned}
& F_{\Lambda}(l)=P(\Lambda<l)=1-e^{-v l} \\
& f_{\Lambda}(l)=v e^{-v l}
\end{aligned}
$$

となる。このとき $\Lambda$ の平均値 $\mu_{\Lambda}$ は $\mu_{\Lambda}=1 / v$ である。

この確率モデル検証のため節径を調查したものと同じラミナを 対象に，節と節の材長方向の間隔 $\Lambda$ につて実測を行った。ラミ ナの面上において節は 2 次元的に分布しているため，材長に沿っ た方向の節間隔 $\Lambda$ はラミナの幅 $D$ によって整理される。Table 2 は 各ラミナ幅における節間隔 $\Lambda$ の統計結果を示したもの, Fig. 3 は $D=90 \sim 110 \mathrm{~mm}$ ，および $D=236 \mathrm{~mm}$ のラミナにおける $\Lambda$ のヒストグ ラムを示したものである。ムの確率分布形は $d$ と同様右に裾の伸び た形状であり，K-S 検定の結果，D=90〜110mmでは指数分布が, Dが184mm以上のところでは指数分布およびガンマ分布が高い適 合度を示した。また，変動係数 $\delta_{\Lambda}$ はどのDでもほほ一定值となっ た。これより，材長方向の節の出現はポアソン確率過程でモデル 化可能である。なお， $D$ に影響を受ける平均值 $\mu_{\Lambda}$ に関しては $\mu_{\Lambda}$ と $D$ が反比例すると仮定し回帰した次式

$$
\mu_{\Lambda}=\frac{2.98 \times 10^{4}}{D-29.9}
$$

でモデル化する。Fig. 4は上式と実測データとの関係を示したもの で，良い対応を示している。

\section{3 有節ラミナの縦引張強度}

大断面集成材梁の曲げ耐力は, 梁のせい・スパン比があまり大 きくない場合には引張側最外層のラミナの引張破壊によって決定 される。したがって，最外層ラミナに存在する節等の欠点が集成 材梁の酎力に大きな影響を与えるといえる。こうした点を考虑し， ここでは節を有するラミナの縦引張強度実験を行い，曲げ耐力評 価のための基脴的な統計デー夕を提供する。

木質材料の引張試験を行う場合, 試験片部分の引張応力度が断 面内で均一になるようにする必要がある。そこで本実験では，節

\begin{tabular}{|c|c|c|c|c|c|}
\hline $\begin{array}{c}\text { Range of } \\
\text { dID }\end{array}$ & The number of Data & $\begin{array}{l}\text { Mean } \\
\mu . \\
(\mathrm{mm})\end{array}$ & $\begin{array}{c}\text { Standard } \\
\text { deviation } \\
\sigma . \\
(\mathrm{mm})\end{array}$ & $\begin{array}{c}\text { Coefficient of } \\
\text { variation } \\
\delta .\end{array}$ & $\begin{array}{l}\text { Fitted Probability } \\
\text { Distribution }\end{array}$ \\
\hline$d$ & \multirow{4}{*}{1304} & 16.81 & 12.73 & 0.757 & Lognormal \& Gamma \\
\hline$d_{i:}$ & & 16.70 & 14.57 & 0.873 & Lognomal \\
\hline$d$, & & 18.21 & 16.34 & 0.897 & Lognormal \\
\hline$d_{s}$ & & 15.02 & 10.35 & 0.689 & Lognormal \& Gamma \\
\hline
\end{tabular}

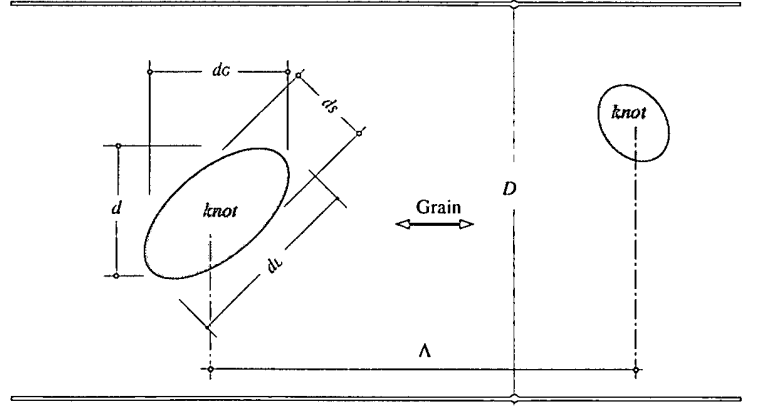

Fig. 1 Dimensions of knot

Table 1 Statistical properties of $d$

\begin{tabular}{|c|c|c|c|c|c|c|}
\hline $\begin{array}{c}\text { Width of } \\
\text { Laminae } \\
D \\
(\mathrm{~mm}) \\
\end{array}$ & $\begin{array}{c}\text { Mean of D } \\
\mu n \\
(\mathrm{~mm})\end{array}$ & \begin{tabular}{|c|} 
Number of \\
Data \\
$N$
\end{tabular} & $\begin{array}{l}\text { Mean } \\
\mu \wedge \\
(\mathrm{mm})\end{array}$ & $\begin{array}{c}\text { Standard } \\
\text { Deviation } \\
\sigma \wedge \\
(\mathrm{mm})\end{array}$ & $\begin{array}{c}\text { Coefficient of } \\
\text { Variation } \\
\delta_{A}\end{array}$ & $\begin{array}{l}\text { Fitted Probability } \\
\text { Distribution }\end{array}$ \\
\hline $90-110$ & 101 & 269 & 425.2 & 383.2 & 0.901 & Exp. \\
\hline 184 & 184 & 335 & 197.5 & 183.5 & 0.929 & Exp. \& Gamma \\
\hline 236 & 236 & 372 & 140.3 & 129.2 & 0.921 & Exp. \& Gamma \\
\hline
\end{tabular}

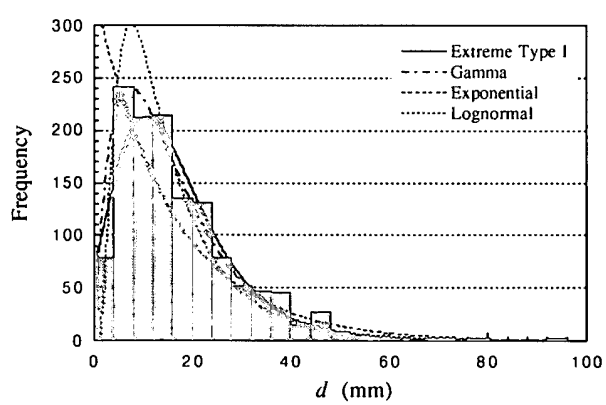

Fig. 2 Histogram of $d$

Table 2 Statistical properties of $L$

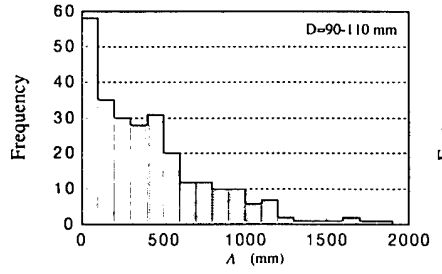

(a) $D=90-110 \mathrm{~mm}$

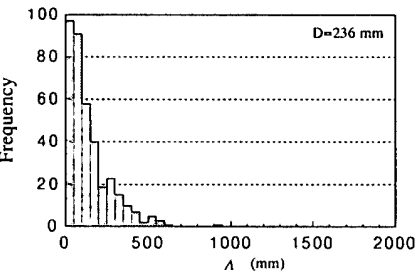

(b) $D=236 \mathrm{~mm}$
Fig. 3 Histograms of $\Lambda$

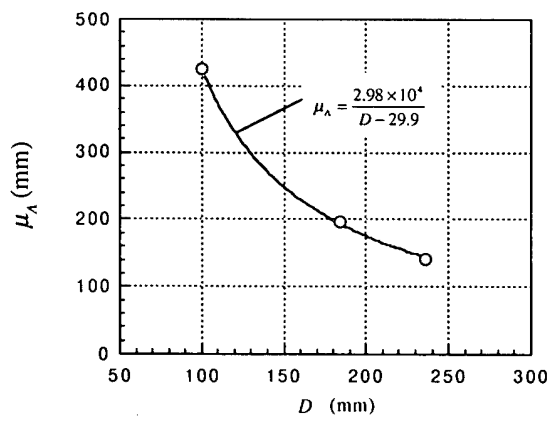

Fig. $4 D$ vs. $\mu_{A}$ relations 
径および節間隔の調查を行ったラミナから，試験片部分の板厚が 掴み部分よりも薄くなるように製材した引張試験体98体を用意し た。試験体には極端な目切れが無いものを選定している。試験体 形状および寸法を Fig. 5 に, 試験体の節径比の範囲と試験体数を Table 3 に示す。

試験体の比重および含水率は, 引張試験終了直後に各試験体か ら直方体の試験片を節や割れを含まないように切り出して測定し

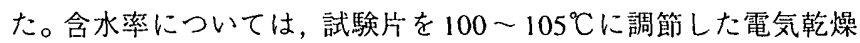
機によって恒量に達するまで乾燥させ，乾燥前後の重量から算出 した。全引張試験体を対象にした測定では，含水率が平均 $11.3 \%$, 変動係数 $12.0 \%$, 比重については平均 0.53 , 変動係数 $12 \%$ である。 また, 平均年輪幅は $3.3 \mathrm{~mm}$, 変動係数は $35 \%$ であった。節は試験 体並行部分のほほ中央に存在するように製材し，試験体の節に関 しては，節材の㵶維と周辺材の綫維との連絡がない死節と，節材 の㵶維と周辺材の繊維が力学的に連続している生節の両方が含ま れるように試験体を選択した。死節と生節の試験体数はそれぞれ 38 体と 45 体である。また, 同一のラミナから節のない試験体も 15 体用意した。節径比算出に用いる節径は，材長と直角方向の径 $d$ に加え, 材長方向の節径 $d_{G}$, 長径 $d_{L}$, 短径 $d_{S}$ も合わせて測定し た (Fig. 2参照)。載荷は, 万能試験機で試験体を直接掴んで引張 ることにより行った。

実験で得られたラミナの最大引張応力度 $\sigma_{T}$ と 4 種類の節径の関 係について最小自乗法によって回帰を行った結果を Table 4 に示 す。回帰は線形関数と指数関数について行った。表中 $r$ は回㷌式に 各節の $d / D$ を代入して求められる引張強度 $\sigma_{T, r e g}$ と実験による $\sigma_{T}$ と の相関係数を表す。また，ラミナ幅方向の節径から算出した節径 比 $d / D$ と引張強度 $\sigma_{T}$ の相関図を Fig. 6 に示す。図中○は生節,

は死節を表し，死節のみを対象とした回帰曲線も併せて戝中に示 した。示にはかなりのばらつきがみられるが，dIDが大きくなるほ ど $\sigma_{\tau}$ は急激に低下する傾向が見られた。節径の測定方法の違いと 回㷌式の精度を表す $r$ との関係においては, 特に節径測定方法ごと の有為な差は認められなかった。また，回帰式に見る生節と死節 の有意な差も認められず, 引張強度においては節部分の破壊は節 内部への応力伝達状態よりも節周辺の繊維の乱れの影響が大きい

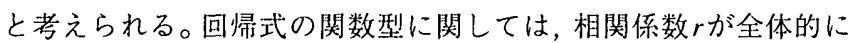
線形関数よりも指数関数の方で高いこと, $d / D=0 に お け る$ 無欠点 ミナのデータとの整合性等を考虑すると，指数関数でモデル化す る方が妥当と言える。

Table 5 は，節径比 $d / D$ を各デー夕数がほぼ等しくなるように 5 つの区間に分け，それぞれの区間内で引張強度 $\sigma_{T}$ の統計值を示し たものである。また，Fig.7はそれらの統計值を実験值と併せてプ ロットしたものである。平均值は指数関数による回㷌式と非常に 良い対応を示した。また，ばらつきに関しては，d/Dが $0 〜 0.210$ の範围で最も標準偏差が大きくなったが，変動係数に換算すると dIDの増加に伴ってほほ単調に増加する傾向がみられた。試験体数 の関係から，各区間内での分布形状を考察するほど十分なデー夕 は得られていないが，今後さらに実験データが立実されれば， $d I D$ の変化に伴う $\sigma_{T}$ のばらつきや分布形状の変化について定量化を 行っていく必要がある。

なお，本実験では試験片部分のラミナ幅が比較的薄く，節がラ

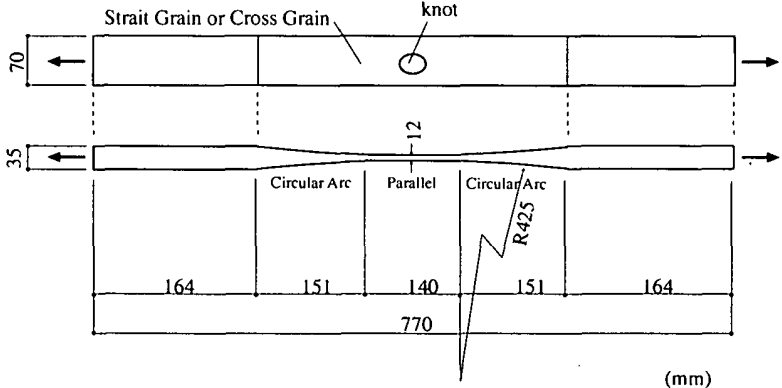

Fig. 5 Dimensions of test specimens

Table 3 Test specimens

\begin{tabular}{c|c|c|c}
\hline Range of $d / D$ & Mean of $D / d$ & The Number of Data & Frequency (\%) \\
\hline 0.0 & 0.0 & 15 & 15.31 \\
\hline $0.0-0.2$ & 0.174 & 11 & 11.22 \\
\hline $0.2-0.4$ & 0.290 & 44 & 44.90 \\
\hline $0.4-0.6$ & 0.510 & 19 & 19.39 \\
\hline $0.6-0.8$ & 0.628 & 6 & 6.12 \\
\hline $0.8-1.0$ & 0.883 & 3 & 3.06 \\
\hline
\end{tabular}

Table 4 Regression formulae and correlation coefficients

\begin{tabular}{|c|c|c|c|c|c|c|}
\hline \multirow[t]{2}{*}{$\begin{array}{l}\text { Parameter } \\
\text { of Knot }\end{array}$} & \multicolumn{3}{|c|}{$\sigma_{r, r_{x}}=\alpha \cdot e^{-\beta}\left(\frac{d}{n}\right)\left(\mathrm{kN} / \mathrm{cm}^{2}\right)$} & \multicolumn{3}{|c|}{$\sigma_{t, r \mathrm{x}}=-\alpha \cdot\left(\frac{d}{D}\right)+\beta \quad\left(\mathrm{kN} / \mathrm{cm}^{2}\right)$} \\
\hline & $\alpha$ & $\beta$ & $r$ & $\alpha$ & $\beta$ & $r$ \\
\hline$d$ & 9.86 & 3.31 & 0.896 & 12.28 & 8.41 & 0.835 \\
\hline$d_{i_{i}}$ & 9.16 & 2.83 & 0.902 & 9.93 & 7.94 & 0.810 \\
\hline$d_{L}$ & 9.43 & 2.74 & 0.909 & 2.74 & 8.10 & 0.821 \\
\hline$d_{s}$ & 9.14 & 3.29 & 0.878 & 11.96 & 8.05 & 0.807 \\
\hline
\end{tabular}

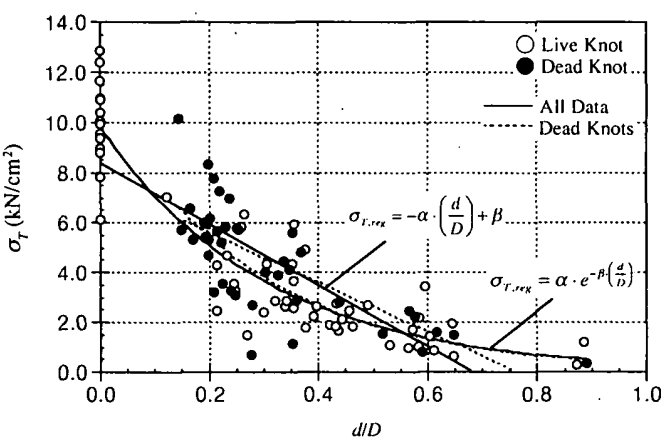

Fig. $6 d / D$ vs. $\sigma_{T}$ relations

Table 5 Statistical properties of $\sigma_{T}$

\begin{tabular}{c|c|c|c|c|c|c}
\hline Range of d/D & $\begin{array}{c}\text { The number of } \\
\text { Specimens }\end{array}$ & Mean of $d / D$ & $\begin{array}{c}\text { Mean of } \sigma r \\
\left(\mathrm{kN} / \mathrm{cm}^{2}\right)\end{array}$ & $\begin{array}{c}\text { Mean of } \sigma, \mathrm{im} \\
\left(\mathrm{kN} / \mathrm{cm}^{2}\right)\end{array}$ & $\begin{array}{c}\text { Standard } \\
\text { deviation of } \sigma, \\
\left(\mathrm{kN} / \mathrm{cm}^{2}\right)\end{array}$ & $\begin{array}{c}\text { Cofficient of } \\
\text { variation of } \sigma,\end{array}$ \\
\hline 0.000 & 15 & 0.000 & 9.80 & 9.86 & 1.66 & 0.169 \\
\hline $0.000-0.210$ & 23 & 0.174 & 6.01 & 5.54 & 2.14 & 0.357 \\
\hline $0.210-0.326$ & 23 & 0.267 & 4.13 & 4.08 & 1.73 & 0.418 \\
\hline $0.326-0.521$ & 23 & 0.393 & 3.00 & 2.68 & 1.19 & 0.398 \\
\hline $0.521-0.881$ & 20 & 0.629 & 1.50 & 1.23 & 0.81 & 0.540 \\
\hline
\end{tabular}

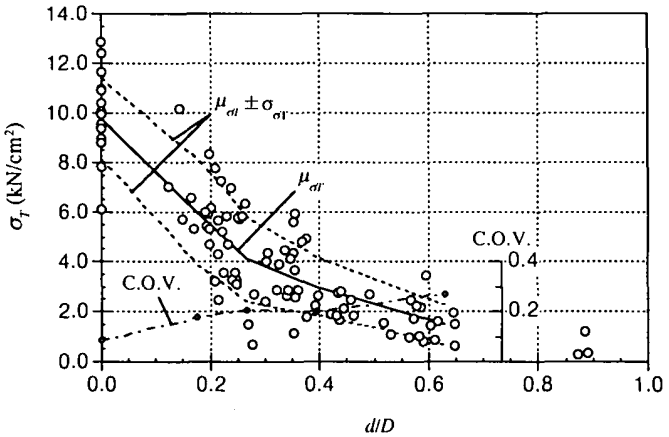

Fig. 7 Histograms of $\sigma_{T}$ 
ミナの幅方向に対してほほ中央に存在する場合を対象に試験体を 作成したが, 有節材の引張強度については板厚や節の材縁からの 距離との関係についても報告がなされており9!1, これらの関係が 統計的に明らかにされればその影響も含めた確率論的な強度評価 が必要である。

\section{3.節径比と節強度のランダム性を考慮した有節ラミナの引張強度}

前章では節径比と縦引張強度の関係についてその統計的な諸量 を明らかにしたが，節は当然その節径の出現頻度についてもラン ダム性を有する。そこで，本章では，前章までで得られた節強度 の統計量と，節径比の出現頻度のランダム性の両方を考慮した節 部分の耐力を解析的に求め，その統計的な性質について考察を行 う。

\section{1 節のランダム性を考慮したモンテカルロシミュレーション}

Table 4で示した指数関数による回㷌式 $\sigma_{T, r e g}$ 回りの実験結果 $\sigma_{T}$ の ばらつきを考察するため, $\sigma_{\tau}$ を $\sigma_{T, r e g}$ で無次元化した值 $\sigma_{0}\left(=\sigma_{T} / \sigma_{T, r e s}\right.$ )のヒストグラムをFig. 8に示す。ここではラミナの幅方向の節径 dを用いた節径比に対する回帰式を用いて統計処理を行っている。 $\sigma_{0}$ の平均值は 0.927 , 標準偏差は 0.328 であり, K-S 検定の結果ガ ンマ分布が高い適合度を有した。

有節ラミナの引張強度は, 節径比のランダム性と, 節径比と強 度の関係のランダム性の両方を考慮して評価される必要がある。 いま，1つの節を有するラミナの引張強度を $\sigma_{T 1}$ とすると， $\sigma_{T 1}$ は 節径を表す確率変数 $d$, 回㷌式からのばらつきを表す確率変数 $\sigma_{0}$, そしてTable 4 に示した指数関数による回帰結果を用いて次式のよ うに表すことができる。

$$
\sigma_{T 1}=9.86 \cdot e^{-3.31 \cdot d 1 D} \cdot \sigma_{0}
$$

そこで,この $d$ と $\sigma_{0}$ の 2 つのランダム性を考慮した引張強度の統 計的性質を，モンテカルロシミュレーションを用いて検討する。シ ミュレーションでは, Fig. 2で示した統計量を有する対数正規分布 に従う節径の乱数データ $d\left(d_{1}, d_{2} \cdot \cdots, d_{n}\right)(n=10,000)$ ，および Fig. 8 で示した統計量を有するガンマ分布に従う引張強度の乱数 デー夕 $\sigma_{0}\left(\sigma_{01}, \sigma_{02} \cdots \cdot, \sigma_{0 n}\right)(n=10,000)$ を生成し，各デー夕を (6)式に代入することで引張強度のランダムデータ $\sigma_{T 1}$ を生成した。 こうして得られた $\sigma_{T 1}$ について $D=90 \mathrm{~mm}$ と $D=150 \mathrm{~mm}$ の場合のとス トグラムを示したのがFig. 9である。Dが大きくなると相対的に節 径比が小さくなるため， $\sigma_{T 1}$ の分布形状は $D=150 \mathrm{~mm}$ の方が右にシ フトした形となる。Fig. 10 は $\sigma_{T 1}$ の平均值 $\mu_{T 1}$ と変動係数 $\delta_{r 1}$ をDで 整理して示したものである。確率分布形からも考察できたように 平均值 $\mu_{T 1}$ は $D$ が増加するに従って大きくなるが, 変動係数 $\delta_{T 1}$ は

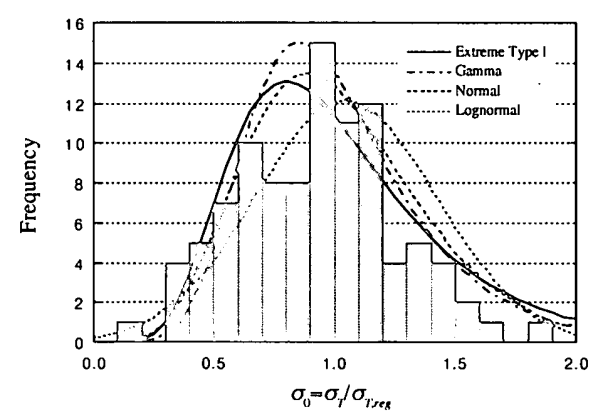

Fig. 8 Histogram of $\sigma_{0}$

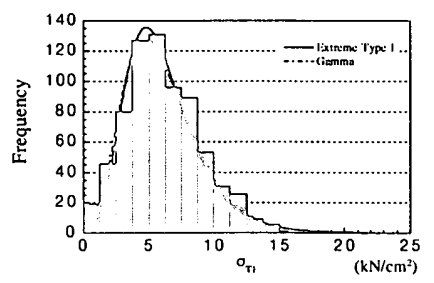

(a) $D=90 \mathrm{~mm}$

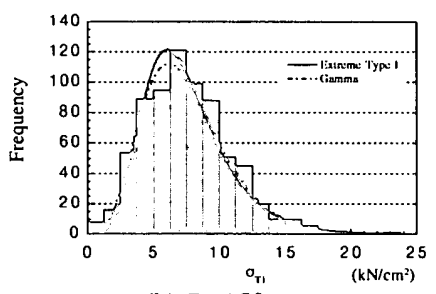

(b) $D=150 \mathrm{~mm}$
Fig. 9 Histograms of $\sigma_{T 1}$

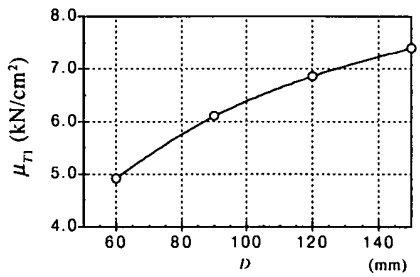

(a) Mean value

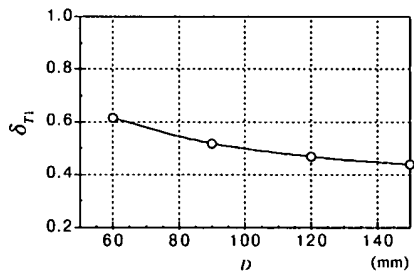

(b) Coefficient of variation
Fig. 10 Mean value and coefficient of variation of $\sigma_{r t}$

やや減少する傾向が見られた。なお， $\sigma_{T 1}$ については K-S 検定の結 果，Dに関わらずガンマ分布および極值 I 型分布との適合が確認 できた。

\section{2 節の出現頻度を考慮した引張強度}

前節では 1 ケ所の節を対象とした引張強度について検討を行っ たが，ある長さを持ったラミナ上には当然複数の節が存在する可 能性がある。いま，材長方向に引張を受けるラミナの長さを $L$ と すると，長さ $L$ の間に $i$ 個の節が存在する確率 $P(L, i)$ は，

$$
P(L, i)=\frac{(v L)^{i}}{i !} e^{-v}
$$

となる。ここにvは単位長さ当たりの節の平均存在数であり, ベイ マツの場合 2 章の結果より,

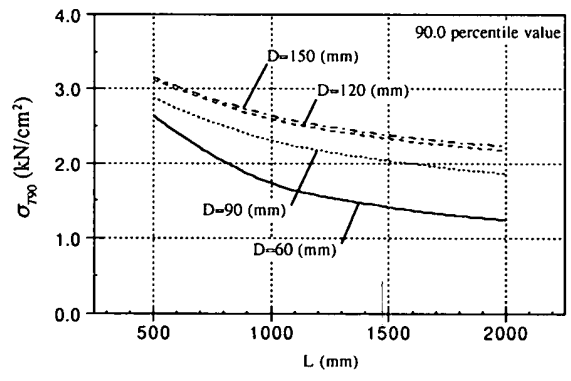

(a) 90.0 percentile strength

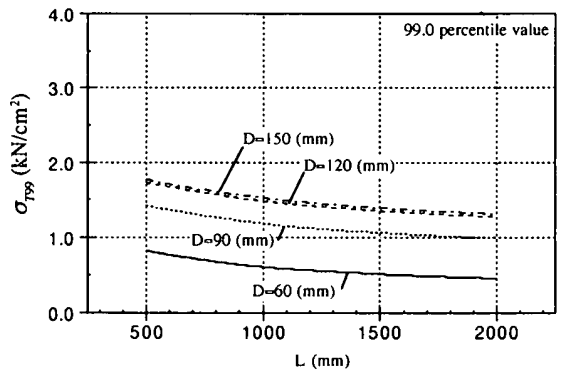

(b) 99.0 percentile strength

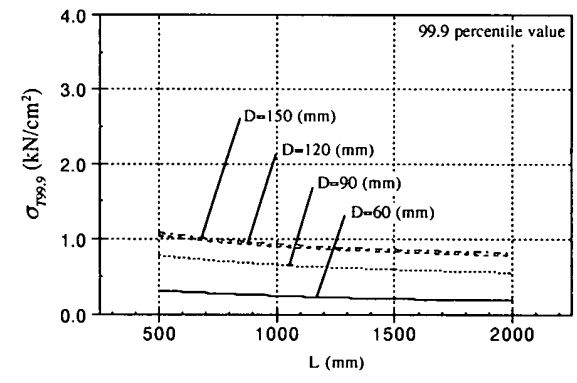

(c) 99.9 percentile strength

Fig. 11 Percentile value of $\sigma_{T_{n}}$ 


$$
v=\frac{1}{\mu_{\Lambda}}=\frac{D-29.9}{2.98 \times 10^{4}}
$$

となる。ラミナの引張強度は複数の節のうち酎力が最小のもので 決定されると仮定すると, $i$ 個の節の存在を考慮した引張耐力の確 率分布関数 $F_{T i}$ は次式となる。

$$
F_{7 i}(x)=1-\left\{1-F_{T 1}(x)\right\}^{i}
$$

ここに, $F_{r 1}$ は1つの節の存在を仮定した場合の引張強度 $\sigma_{T 1}$ の確 率分布関数であり，前節の結果に基づけば $F_{T 1}$ はラミナ幅 $D$ に対応 してFig. 10に示す平均值と標準偏差を持つガンマ分布でモデル化 できる。(6) (8)式を用い, 節が存在しない場合や複数の節が存在す る場合も考慮した引張強度の確率分布関数 $F_{T n}$ は次式のように求め られる。

$$
F_{T n}(x)=F_{T 0}(x) \cdot P(L, 0)+\sum_{i=1}^{\infty} F_{7 i}(x) \cdot P(L, i)
$$

ここに $F_{T 0}$ は無節ラミナの引張強度の確率分布関数であり,ここで はTable 5で示した実験結果に基づき, 平均值 9.80 , 変動係数 0.169 のガンマ分布でモデル化する。

Fig. 11 は(9)式から得られる確率分布関数を用い, 非超過確率が $90 \%, 99 \%$ および $99.9 \%$ となるような引張強度の下限值 $\sigma_{790}, \sigma_{799}$ お よび $\sigma_{T 99.9}$ を引張材の材長 $L て ゙$ 整理して示したものである。まず材 長 $L$ の変化に対する影響を見ると，いずれの非超過確率に対して もLが大きくなるほど下限值が小さくなっている。これは長い材 ほど引張応力を受ける区間内に存在する節の数が増加するためで ある。この影響は非超過確率の小さいときほど，また，ラミナ幅 が小さいものほど顕著になっている。次にラミナ幅の影響を考察 すると, 幅の小さいラミナほど引張強度の下限值は小さくなって いるが, Dが $120 \mathrm{~mm}$ 以上では下限値の差はほとんどなくなってい る。これは，同一径の節が存在した場合には幅の小さいラミナほ ど相対的に節径比が大くなることから節部分の強度も大きく低下 し，かつこの低下の影響はラミナ幅が大きくなることによる存在 節数の増加の影響よりも敏感であるためと考えられる。

\section{4. 節径比によるラミナのグレーディングと引張強度評価}

集成材の強度低下に大きく影響をおよはすすうな節は，ラミナ を製材する段階でグレーディングし取り除くことが可能である。 本章では，前章の結果に基づき節径比によってグレーディングを 行った場合のラミナの引張強度のシミュレーションを行い, グ レーディングに用いる基準節径比と引張強度の下限值の関係につ いて考察を行う。

シミュレーションの手法は基本的に 3 章3.1節で述べた方法に従 う。節径比によるグレーディングは, 発生させた節径の乱数デー 夕から基準となる節径比以上の大きさの節のデータを取くことで 考慮する。具体的には, Fig. 2で示した統計量を有する対数正規分 布に従う節径の乱数デー夕配列 $d\left(d_{1}, d_{2} \cdot: \cdot d_{n}\right)(n>10,000)$ か ら節径比 $d / D$ が基準節径比 $(d / D)_{\mathrm{grd}}$ 以上のものを取り除いたデー夕 配列 $d_{g}\left(d_{g 1}, d_{g^{2}} \cdot \cdot, d_{g n}\right)(n=10,000)$ を生成し，これを(5)式に 代入することで節部分の引張強度 $\sigma_{r 1}$ に関する統計デー夕を得る。 Fig. 12 はこうして得られた $\sigma_{T 1}$ の平均值 $\mu_{T 1}$ と変動係数 $\delta_{T 1}$ をグレー ディングに用いた基準節径比 $(d / D)_{\text {grd }}$ との関係で示したものである。 いずれのラミナ幅においても $(d / D)_{\mathrm{grd}}$ を厳しくするほど，すなわち

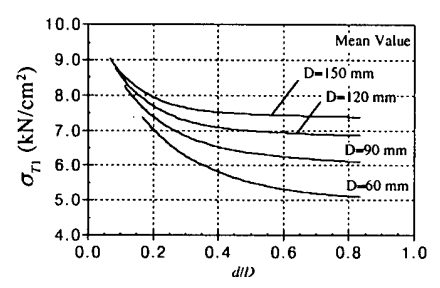

(a) Mean Value

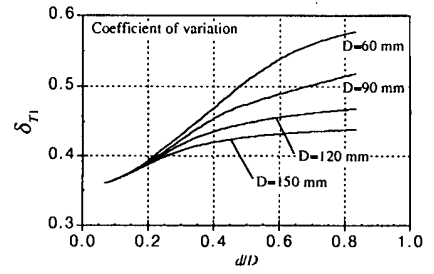

(b) Coefficient of variation
Fig. 12 Mean and coefficient of variation in changing of $d_{\text {grad }}$

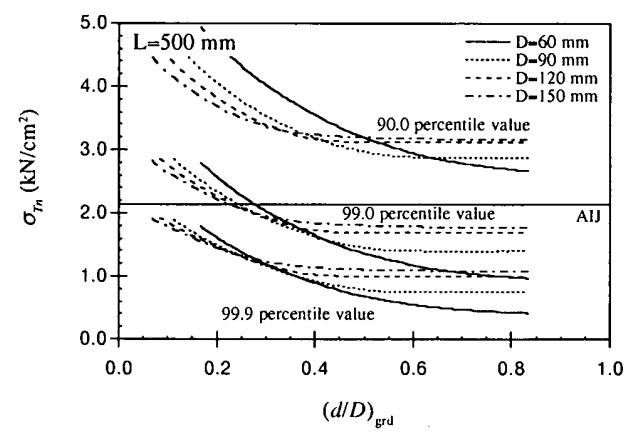

(a) $\mathrm{L}=500(\mathrm{~mm})$

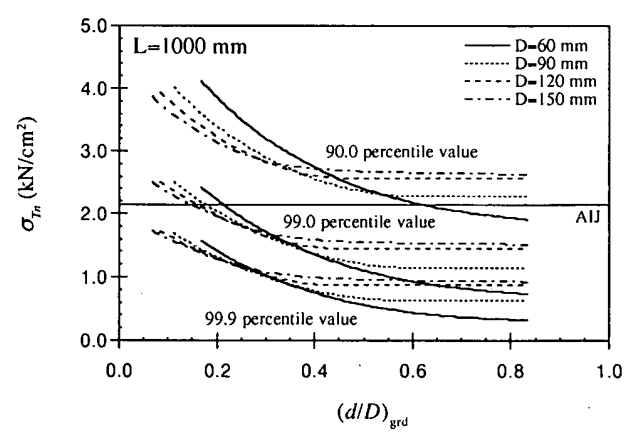

(b) $\mathrm{L}=1000(\mathrm{~mm})$

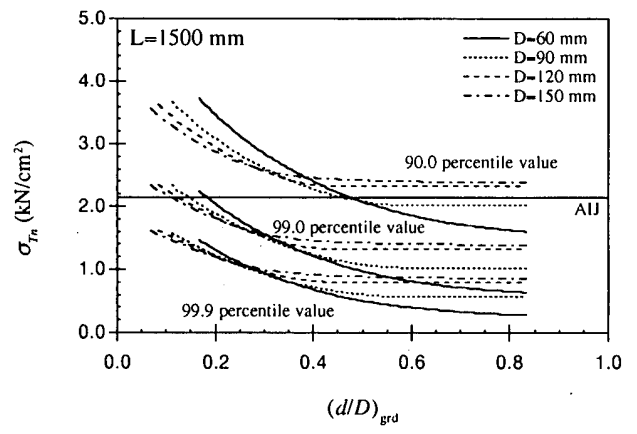

(c) $\mathrm{L}=1500(\mathrm{~mm})$

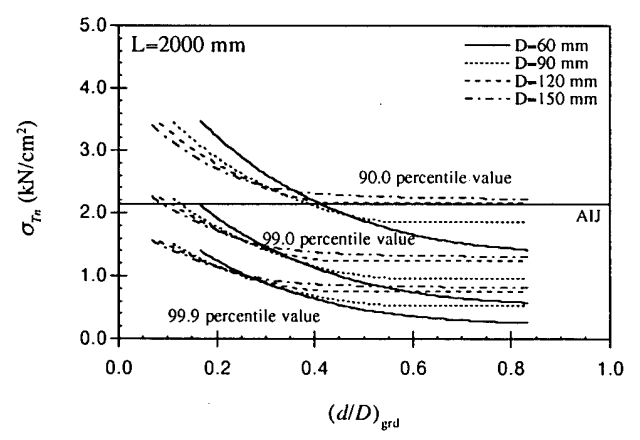

(d) $\mathrm{L}=2000(\mathrm{~mm})$

Fig. 13 Percentile value of $\sigma_{T_{n}}$ vs. $(d / D)_{\text {grd }}$ 
$(d / D)_{\mathrm{grd}}$ を小さく設定するほど平均値は上昇し，変動係数は小さく なっている。また，ラミナ幅ごとの差も $(d / D)_{\text {grd }}$ が小さくなるほど 減少し, $(d / D)_{\mathrm{grd}}$ が2.0以下では変動係数の差はほとんどなくなって いる。

以上のようにして得られた節部分の引張強度の統計值を用い, ここでは引張材の酎力に関して考察を行う。節の引張強度の確率 分布関数 $F_{T_{n}}$ に関しては前章同様(8)(9)式に基づいて算定するが, (8) 式の $F_{T 1}$ はFig. 12で示した平均值と変動係数を有するガンマ分布で モデル化する。Fig. 13はこうして得られた $F_{T_{n}}$ に基づき，90\%，99 $\%, 99.9 \%$ 各非超過確率に対応する引張強度の下限值 $\sigma_{T 90}, \sigma_{T 99}$, $\sigma_{r 99.9}$ と $(d / D)_{\mathrm{grd}}$ との関係を材長ごとに示したものである。 $(d / D)_{\mathrm{grd}}$ が 比較的大きいときは，等しい非超過確率に対する下限値はラミナ 幅Dが広いほど大きくなっているが， $(d / D)_{\mathrm{grd}}$ を小さくするに従っ てその差は小さくなり, $(d / D)_{\mathrm{grd}}=0.3 \sim 0.6$ 範囲で大小関係が逆に なっている。すなわち, Dの小さい引張材では節径比によるグレー ディングを行うことによって引張強度の下限值を大きく増加させ ることができるのに対し，Dが大きくなるほどグレーディングに よる下限值の上昇割合が小さくなる傾向がある。また，Dが大きく なると $d / D か ゙ 0.5$ を越えるような大きさの節の出現頻度は非常に小 さくなるため, $(d / D)_{\text {grd }}$ が大きな領域ではグレーディングの効果が ほとんどなくなっている。なお，図中には，木質構造設計規準 ${ }^{21}$ で与えられているべいまつ(特級) の構造用集成材の繊維方向の 短期引張許容応力度レベルも併記している。設計酎力に関しては 設計法全体の中で議論していく必要があるが, 99.0\%の非超過確率 を期待する下限值を現行の許容応力度レベルに対応させるために は， $L=1000 \mathrm{~mm}$ のとき $(d / D)_{\mathrm{grd}}=0.15 \sim 0.2$ 程度， $L=2000 \mathrm{~mm}$ のとき には $(d / D)_{g r d}=0.1 \sim 0.15$ 程度とかなり厳しい基準節径比の設定が必 要である。

なおここでの考察は，前述した通り節がラミナの表面かつ中 央に存在するよう製材し，板厚を実大材より比較的薄くした試験 体を対象とした実験データに基づいている。したがって，今後こ れらの要因と引張強度との統計的な関係を含めて評価を展開して いくとともに，樹種ごとのデータの蓄積を行い，本論文で述べた ような有節ラミナの引張強度の系統的な整理を進めていく必要が ある。

5. 結

節径，材長方向の節間隔，および節強度の統計的な性質を調査
および実験によって定量化し，その確率論的なモデルを提示した。 また, それらのデータに基づいて統計的な有節ラミナの引張強度 を示すとともに，ラミナ幅, 引張長さが引張強度の下限値に与え る影響，および節径比によるグレーディングが引張強度の下限值 に与える影響を定量的に考察した。これらの結果から，ラミナの 引張強度は節の持つランダム性が与える統計的な影響とグレー ディングによる品質管理と併せて考慮することによって，より合 理的に評価することが可能である。

\section{謝 辞}

本研究の一部は平成 8 年度文部省科学研究費補助金奖励研究 （A）によった。また引引張強度実験に関しては愛知産業大学卒論 生山本理恵子氏に御協力いただいた。付して感謝いたします。

\section{<参考文献 $>$}

1）井戸田秀樹，塩沢和訓：有節ラミナの縦引張強度に関する統計論的評価, 日本建築学会東海支部研究報告集，第34号，pp.301-304，1996年2月

2）塩沢和訓, 井戸田秀樹：有節ラミナの綻引張強度に関する統計論的考察そ の 1 縦引張強度実験, 日本建築学会大会学術講演梗概集, 構造III, pp.9-10, 1996年9月

3) 田中 学, 井戸田秀樹, 塩沢和訓 : 有節ラミナの維引張強度に関する統計 論的考察 その 2 節のランダム性を考慮した引張強度評価, 日本建筑学会 大会学術講演梗概集, 構造III, pp.11-12, 1996年9月

4) 角谷 和男：本材強度のばらつき, 材料, 第12巻121号, pp.42-45, 1963 年10月

5 ）小野徽郎，井戸田秀樹，陳 建宏：集成材の曲げ酎力に関する確率論 的研究, 日本建築学会大会学術講演梗概集, 構造II, pp.7-8, 1991年9月

6) 井戸田秀樹，小野徹郎：欠点の位置・強度のランダム性を考慮した木 質集成材の曲げ酎力, 日本建築学会東海支部研究報告集, pp.229-232, 1992年2月

7 ) Czmoch, I., "Lengthwise Variability of Bending Strength of Timber Beams", Structural Safety and Reliability, Proc. of ICOSSAR,93,Vol. 1, pp.569-576, 1993

8）中井 孝: 構造用製材の実大縦引張強度, 日本建筑学会大会学術講演 梗概集, 昭和 59 年 10 月

9 ) 畑山議男: 有節材の強度推定に関する研究, 林業試験場研究報告第 326 号, 1984 年

10）二宮佐知子，板垣直行，三橋博三，野村希晶：集成材ラミナの引張破 壊に及ほす節の影響評価のための実験的研究(II) 引張破壊に及ほす節 の影響に関する考察, 日本建築学会大会学術講演梗概集, 構造III, pp.78,1996 年 9 月

11）二宮佐知子, 板垣直行, 三橋博三：集成材ラミナの引張破壊における 欠点の影隌に関する研究 (2) 節に掞ける破壊のモデルと強度の評価 式, 日本建筑学会大会学術講演梗概集, 構造 III, pp.9-10，1997年 9 月 12）日本建築学会：「木質構造設計規準・同解説」，1995 年 1 月 